\title{
Internal versus external European air market realities: the competitive divide
}

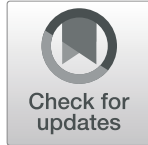

\author{
Darren Ellis
}

\begin{abstract}
Background: This paper looks at how ongoing attempts to improve air market competitiveness in Europe are challenged by the differing internal and external realities that exist. Europe's internal multilateral single air market has encouraged the proliferation of pan-European airlines unhindered by national borders, which have stimulated increased competition and driven down airfare prices. Meanwhile, externally the bilateral system continues to dominate the wider global airline industry and a number of countries still prefer to negotiate air access with individual European countries.

Methods: Data from a five stage mixed-method Delphi study underpin the paper. Qualitative data, collected at a first stage brainstorming workshop and during final stage in-depth interviews, were thematically analysed to locate key and sub-themes. Quantitative survey data were collected across the remaining stages and were statistically analysed with mostly t-tests and chi-square tests of association to a 95\% confidence level.
\end{abstract}

Results: The key theme transferability of the European regional single air market emerged from the study data; supported by the three sub-themes EU regional model, extraterritoriality and North Atlantic single air market.

Conclusions: Europe remains the multilateral exception to the general rule in international aviation that bilateralism is the norm. Despite efforts to address this competitive divide, aeropowers like China and Russia are reluctant to embrace extensive change, while major European flag carriers resist unfettered competition from outside the bloc.

Keywords: Single air markets, European aviation, Bilateral system, Multilateralism, Liberalization

\section{Introduction}

This paper aims to investigate the evident competitive divide which exists between internal and external air market realities in Europe. In this context, competitive and environmental efficiencies are more readily achievable within the internal single European air market than they are externally. The European Common Aviation Area (ECAA), covering almost 40 countries in 2019, is the most far-reaching and comprehensive multilateral single air market in the world today [9]. The European single air market progressively evolved throughout the late 1980s and 1990s across three reform packages driven by the European Commission (EC), the executive arm of the European Union (EU) [12, 15]. This supranational top down approach saw a once fragmented and

Correspondence: Darren.Ellis@cranfield.ac.uk

Air Transport Management, Cranfield University, Cranfield, UK nationally-based market architecture give way to a more open regional market place [12], together with the birth of transnational pan-European low cost carriers (LCCs) such as Ryanair, easyJet and Wizz Air. Although attempts are ongoing to mirror this commercial market achievement in the air space management sphere through the Single European Sky (SES) initiative, Europe nonetheless has still managed to create a multilateral regional single air market the likes of which no other part of the world has been able to replicate to date. This has generated a number of associated telling questions, including; does the European single air market represent a unique experience? Or alternatively, is the European experience a precursor, or indeed model, of things to come for the global aviation industry elsewhere in future?

Global aviation and multilateralism are ubiquitous in terms of safety and technical matters affecting the global industry, but patchy and uneven when it comes to the 
economic and political realms. In this context, air market access achieved via the granting of air traffic rights embedded in air service agreements (ASAs) - essentially international trade treaties - help to maintain a tightly held web of bilateral country to country agreements that form the architecture of most of the global industry. This bilateral system is further strengthened by ownership, control, home base and airline citizenship rules and restrictions that both generate and reinforce the national foundations of the industry [15]. Liberalized bilateral agreements "have typically allowed competition to develop, but not trade"; thus, only airlines with citizenship credentials are able "to participate in a route market between other countries" ([10], pp. 212-213).

There has been remarkable growth and expansion of international aviation in the century following the first commercial aviation passenger flight in Florida in January 1914 [34]. The global aviation industry has grown into a massive sector that employs millions of people worldwide, carries several billion passengers annually, and contributes trillions of US dollars worth of economic activity each year [17]. This impressive industry growth has unfolded alongside an ongoing divide between sovereignty versus freedom; essentially, a debate over the extent to which the nation-state or the marketplace should govern the sector's development [34]. Air market liberalization and protectionism have become synonymous with this freedom versus sovereignty divide [6]. This divide is perhaps better characterized as a range of views according to Nayar [28] who noted several decades ago that the polar opposite positions of free market and nation-state exist "in theory, but always with strong reservations" (p. 146).

The fact that the US domestic air market went through a rapid "big bang" approach to deregulation in 1978 ([35], p. 229), while Europe adopted a more gradual process of liberalization [20], goes some way to demonstrating the cross-border challenges that multilateral air market initiatives face [28, 29]. However, although Europe's liberalization journey reflects the difficulties associated with getting multiple countries to all agree, it still achieved what all other regions have be unable to do so to date $[12,29]$. Many argue that without the supranational power exercised by the EC, Europe's single air market would have been far less ambitious or extensive in the end $[12,15]$. Europe's multilateral single air market essentially means its acts as "one nation" in an internal aviation context ([19], p. 41). Even so, not all countries outside Europe treat it as such, preferring instead to deal with each individual member country separately [15]. Despite such shortcomings, it is fair to say that by the early 2000s, "the EU [had] emerged as a new actor in international aviation" ([1], p. 239).

The EU is keen for other countries to recognize its community carrier designation and to sign horizontal agreements with it as a single entity, rather than the traditional bilateral agreements agreed with each individual EU state $[15,33]$. Although progress has certainly been made on this front with countries such as China warming to the practice [33], the potential of this approach remains stifled by its partial and often heavily restricted adoption. Even if the EU community carrier concept is widely accepted and recognized throughout the world, each horizontal agreement would then effectively become a bilateral agreement between the EU single air market and each separate country, much like the 2008 EU-US open skies agreement [3]. Even this latter agreement prevents cabotage (i.e. domestic services by a foreign airline) within the US domestic air market, but allows fifth freedom rights to US carriers between EU member states. Thus, each country in Europe is treated as a single state in this aspect of the agreement [4].

\section{Methodology}

The methodology that underpins this paper is a five stage mixed-method Delphi study which looked at the likely future trajectory of the global airline industry over a 10 year timeframe and was conducted in 2013 and 2014. Although collected over 5 years ago, the study's data directly related to Europe remain salient as most major considerations have not dramatically shifted to date. The Delphi method is essentially a forecasting technique that continues to be widely employed in scholarly research, including in air transportation studies [25, 27]. Delphi studies typically unfold across several rounds and have historically involved only experts and a quest for consensus agreement. More recently, the Delphi method has evolved to now encourage maverick opinions, laypeople (i.e. non-experts) and divergent viewpoints $[2,16]$. A significant amount of Delphi research is now founded on "the ability to simply ... discuss and refract ideas" ([21], p. 54). A number of Delphi practitioners now argue that "a free exchange of conflicting views" is better than trying to achieve consensus ([36], p. 203). Taking this into consideration, consensus was utilized in this study to act as a reference point, but not to the extent that it stifled "innovative ideas" or ignored differing viewpoints ([27], p. 77). As elsewhere, consensus was set at $75 \%$ agreement/ disagreement or higher [25].

The exploratory Delphi method followed in this study involved a sequential series of five stages beginning with a brainstorming workshop $(n=5)$, a pilot survey $(n=12)$, a main survey $1(n=122)$, a main survey $2(n=34)$, and lastly, in-depth semi-structured interviews $(n=13)$. These stages reflect key elements from a classical Delphi, a hybrid Delphi (i.e. the workshop), along with an eDelphi study as all three surveys used were online. Expert was only determined 
and defined at the completion of the main survey 1 $(n=122)$, with 71 respondents labelled as expert once the parameters had been decided. The final two stages involved experts only. Two self-rated background survey questions were used to define expert in this study; these were level of industry knowledge (minimum of good), and years of airline industry knowledge and/or experience (minimum of 6 to 10 years). Both minimum requirements had to be achieved for a participant to be labelled expert.

The first stage workshop deliberately included a maverick participant who was willing to challenge conventional industry thinking, based on previous interactions with the study's researcher; an approach recommended in the Delphi literature [2]. As a result, the other workshop participants on many occasions were encouraged to expand and clarify their often economically focused responses. In consequence, international relations and geographical location emerged as key topic areas to better understand the global airline industry, including its likely future prospects and trajectory. The next stage was a pilot survey which intentionally involved laypeople, together with people with evident expertise in international aviation. This approach directly led to the main survey 1 (stage 3 ) being more user-friendly than would otherwise have been the case as those with little to no subject matter expertise tended to provide feedback on the survey's overall style and ease of completion. This feedback led to the predominantly paragraph-style questions being replaced with mostly multiple choice questions (MCQs). Several such pilot survey participants provided feedback on the examlike feel of the pilot survey, and suggested MCQs as the solution.

The main survey 1 contained 18 MCQs, while the subsequent main survey 2 was structured around 27 forecasts (see appendix), informed by and with embedded feedback from the main survey 1 . Each main survey had the same four background questions (i.e. capacity/job, industry knowledge, years of knowledge \& global region/s of best knowledge), while the main survey 2 also asked if respondents had completed the previous survey; all selected yes. As noted above, only defined experts completed the final two stages of the study; that is, the main survey 2 and the in-depth interviews. A comprehensive literature review chapter, together with an industry context chapter, were first developed in order to inform and scaffold the design of the methodology. In addition, Michael Porter's five forces of competition model, combined with the political, economic, social, technological and environmental (PESTE) framework, were used as conceptual frameworks to detail and map "the key concepts and factors to be investigated", and provide a valuable way to capture "emerging, fragmented or broad themes" ([23], p. 200).

A significant amount of contemporary Delphi-based research simply quantifies expertise on the grounds that it reflects a wide spectrum of opinions from a diverse number of participants with enough knowledge of the research field to contribute considered ideas and views [27, 31]. The core aim of this study, as reflected in similar Delphi research in air transportation, was "to gain insight", including "innovative insight" ([8], p. 1025 [6];, p. 1). Such an overarching goal is likewise articulated in other airline industry research as well [23]. Added to this, predicting and forecasting are sometimes referred to interchangeably [38]. In this study, by seeking out key industry insights "a predictive focus" was avoided, and instead a more flexible approach based on forecasting plausible scenarios was adopted ([30], p. 1609).

Study participants were located via purposeful sampling at the 2013 Air Transport Research Society (ATRS) conference (2 months before the workshop), via several online travel and tourism forums, professional bodies, industry associations, university alumni and staff contacts, journal article authors, and also from online media outlets which covered aviation (mostly individual journalists). Added to this, snowball sampling was also employed whereby potential participants were encouraged to share the survey links with others [5, 25].

Four background questions at the beginning of each main survey were used to classify participants, including into the expert category. These questions covered capacity (e.g. academic, airline manager, etc.), level of industry knowledge, years of industry knowledge, and geographical region/s of best knowledge - see distribution of the latter as an appendix. Although experts working and/or studying in an academic capacity were in the majority across both main surveys (67\% \& $76 \%$ respectively), many also evidently had industry experience. However, the single focus background question on capacity did not capture this. Given the global industry level focus of this research, traversing as it did multiple regions and considerations, it is perhaps not surprising that those in academia were in the majority. When a broad cohort of experts are sought and utilised, as in this study, response rates tend to be lower when the research is not directly related to an expert's context [25]. Levels of industry knowledge across both main surveys were Good (34\% \& 23.5\%), Very Good (48\% \& 56\%), and Excellent (18\% \& 20.5\%). Average years of industry knowledge were over 18 years for both surveys, closely mirroring similar Delphi research [22]. 
Study data were either thematically or statistically analysed, with each stage providing feedback for subsequent stages. Thematic analysis sought to uncover key themes and sub-themes (i.e. overarching topic areas and their supporting sub-topics), with this paper anchored to the key theme transferability (i.e. how transferable is European air market multilateralism elsewhere in the world?), and its associated subthemes EU regional model, extraterritoriality and North Atlantic single air market; all covered in more detail in the next section. Statistical analysis centred on either t-tests or chi-square tests of association to a 95\% confidence level. The results and findings explored in this paper are representative of the views of the study experts across the two main surveys and the final stage interviews. Along with percentages and a number of statistical test results, direct quotations from interviewees are used to highlight areas of agreement and disagreement, and to help deepen and clarify insights gained across the surveys.

\section{Transferability of Europe's single air market policies and practices}

The key theme transferability of the European regional single air market model of multilateral liberalization, whether via demonstration or persuasion, needs to be viewed in the overall context of international air market liberalization more widely. Results from this study clearly show that experts were divided on the inevitability of international liberalization covered on the main survey 2 in Forecast 13. This forecast postulated that: Full (or close to it) international air market liberalization is inevitable; the only area of real debate concerns how long it will take to achieve. Nearly half of experts agreed (47\%), although tellingly close to this same number also disagreed (41\%), with $12 \%$ opting for neutral. The results for Forecast 9 on the same survey covering bilateralism help to interpret these results; it argued: Bilateralism will still be a significant force and influence for the global airline industry into the foreseeable future. Eighty-five percent of experts agreed to Forecast 9, the second highest result on the survey (Asian region/Chinese future protectionism achieved $88 \%$ agreement on Forecast 20).

The results for Forecast 9 suggest that the bilateral system is not disappearing from the industry, nor is it likely to face substantial weakening in future. When the results for Forecast 20 are added (88\% agreement), China is revealed as a major reason behind the continued relevance and longevity of the bilateral system. Forecast 20 argued that: Asian countries like China, with actual or potential domestic air markets of significant size, are highly unlikely to grant unrestricted (open) market access to foreign airlines into the foreseeable future (and mostly, if not exclusively, on a bilateral basis only). This forecast attained the highest level of consensus agreement across all 27 forecasts on the main survey 2; $88 \%$ (with strongly agree alone 29\%). Only four experts $(12 \%)$ here chose either neutral (6\%) or disagree (6\%), and none strongly. According to a significant majority of experts in this study, large air markets in Asia (especially China) will not be keen supporters of extensive liberalization. This parallels the opinions of Havel and Sanchez [14] who contend that "rising economic powers such as China and Russia remain leery of highoctane liberalization" (p. 16). Thus, despite some movement in the direction of accepting the European community carrier concept [9], China - much like the US - is not likely to push for, nor support, efforts aimed at substantial regional multilateralism in the foreseeable future [15].

\subsection{EU regional model}

The sub-theme EU regional model emerged from the transferability key theme and adopted the perspective of the European regional single air market as a prime example of what regional multilateralism might look like elsewhere around the world in future. To this effect, Forecast 12 on the main survey 2 contended: Regional single air blocs (single air markets) similar to that currently represented by the EU, will become the dominant market structure for the global airline industry in the next 10 years or so. A majority of experts (62\%) agreed with this assertion, although nearly a quarter disagreed (23\%), while consensus set at $75 \%$ or higher was not reached. Even so, this level of agreement might have been moderated by the timeframe given, and/or by the use of the expression "dominant market structure". The results here are significant enough to suggest that the European model may yet take hold elsewhere according to most study experts, and therefore, progressively challenge the more widespread contemporary bilateral system.

Most interviewees (69\%) felt that there was value in closely considering the implications and lessons from the European airline industry and regional single air market; however, almost all stopped short of classifying it as a global model to be followed elsewhere. This guarded approach to Europe's wider global influence and power is reflected in the air transport literature as well [3, 12, 39]. Interviewee 5 rhetorically asked: "Is it a model? I don't think it is to be honest ... it hasn't really changed a huge amount with respect to international" considerations. Interviewee 7 agreed, arguing that the EU and its single market make "complete sense [but] I see the European example as an anomaly". Interviewee 2 expounded on 
this same point, contending that "the Europeans had a sort of cultural ... advantage; let's be realistic, it's taken them 40 odd years ... even the aviation stuff came in fits and starts". Interviewee 8 followed a similar line of argument, stating that although Europe's single air market represents a good model, it "is not easily replicable in other contexts, because of population, geography, economy and different political systems". Moreover, Interviewee 13 observed that "the [supranational] mechanisms which brought the European Union into a multilateral free market aren't, to be fair, in other parts of the world". He then gave the examples of the Association of South East Asian Nations (ASEAN) and Africa and how neither has an "effective mechanism" to push national governments into collective agreement to turn aspirations into actions. Havel and Sanchez [14] concur with such sentiments, maintaining that the US and China for instance "are equally unenthusiastic about ... supranational institution-making" like that associated with the EU (p. 10).

\subsection{Extraterritoriality}

The sub-theme extraterritoriality covers Europe's power and influence outside its single air market. Evidently, study experts were less optimistic about Europe's aviation power and direct industry influence in this regard. Forecast 11 on the main survey 2 almost achieved consensus agreement (74\%) to the assertion that: In a massive and highly complex system like the global airline industry, the EU can provide interesting insights into its likely future, but beyond that, its power and influence to shape the industry's future development is limited. Only $9 \%$ of experts disagreed here, while the remaining $17 \%$ opted for neutral. The most interesting statistically significant result here was for Europe as a region of best industry knowledge (T-value was 1.778. $P$-value was 0.042$)$. The fact that those experts with best industry knowledge in Europe were more inclined to agree with Forecast 11 (83\%) compared with the group 'other' (i.e. those who did not select Europe), suggests that observations and comments found throughout the air transport literature that highlight Europe's mostly unique journey to a single air market, can be said to be founded on a fairly solid footing $[13,15,37]$.

The notion of Europe using its power and influence to shape the global airline industry's future is encapsulated in its to date unsuccessful attempts to include foreign airlines in its emissions trading scheme (ETS) to combat climate change [26]. Opponents point to the apparent failure of this extraterritorial approach as evidence that the bilateral system in global aviation remains dominant, while supporters of Europe's tactics here highlight how the EU was able to elevate the issue to a global level, and thus encourage the industry to take climate change more seriously $[12,15]$. Results from this study show that the EU ETS failed to achieve majority support (49\%) on Forecast 3 as $a$ likely future model of how to effectively deal with airline industry emissions.

Irrespective of how one looks at Europe's attempts to raise the profile of aviation's contribution to climate change, the fact remains that the internal market dynamics of the European regional single air market are much easier to influence and shape and indeed regulate - than are wider industry issues and considerations outside of safety, security and technical standardization and harmonization [15]. Added to this, Europe's attempts to influence and shape global aviation are seen by some "as divisive" and counterproductive ([11], p. 72). This is clear in the opinions covering the EU ETS voiced by Interviewee 5 who contended that in an international aviation context "you can't just add a tax; I mean that violates a couple of articles in most air service agreements that I have seen". Even so, Button [3] maintains that since the 1990s the European single air market has generated "both knock-on and demonstration effects for [other] regions" around the world (p. 60). Likewise, Pitfield [32] also notes the "demonstration effects" of the 2008 US-EU open skies agreement, claiming that a number of other countries are pondering (and some even pursuing) "similar initiatives" (p. 311). In fact, Europe has followed a policy of negotiating "comprehensive air transport agreements with selected partners all over the world" since the early 2000s; not just to strengthen the industry in Europe, but also to "seek to reform international civil aviation" ([12], p. 428). However, whether such a global reform agenda - poignantly demonstrated via the EU ETS experiences - can move beyond "hortatory resolutions" is an open question at present ([15], p. 231). Similarly, on the broader related topic of multilateral air market liberalization, "it is hard to tell where rhetoric ends and reality begins" ([18], para. 3).

\subsection{North Atlantic single air market?}

If international multilateral liberalization is to ever substantially move beyond the European regional single air market to something even bigger, then the North Atlantic - principally used here to mean Europe and the US domestic air market - has long been touted in the air transport literature as the location most likely for this to occur $[13,28]$. The subtheme North Atlantic single air market emerged from the study's data and primarily sought to gauge the 
likelihood of the US domestic air market merging with the European regional single air market in the foreseeable future. Most experts on the main survey 1 , multiple choice question 15 (MCQ 15), were not very convinced that this would happen anytime soon. The survey question asked: How likely do you think it is that the US and EU will create a single North Atlantic air market in the foreseeable future? Half of the experts for this question opted for either "zero chance" (6\%) or "unlikely" (44\%), while one third (34\%) selected "50/50". Meanwhile, only $13 \%$ chose "likely", and finally $3 \%$ were the most optimistic and elected "almost certain".

One major barrier to a North Atlantic single air market are US airline ownership and control rules, which are some of the most restrictive in the world today [15]. Once again, most experts in this study were not confident change was likely in future. This was shown on the main survey 2, where Forecast 18 contended that: US foreign ownership and control restrictions will not be lifted or eased any time soon. Consensus agreement was almost reached here with $73 \%$ of experts agreeing (26\% strongly). Disagreement only managed $9 \%$ here, of which $3 \%$ was strongly disagree. The remaining $18 \%$ of experts chose the neutral option. On the surface these results might seem at odds with the long history of support the US has shown for open skies agreements; however, a closer look reveals that the US has always pushed a decidedly national interest based agenda in its aviation diplomacy [34]. This US view of open skies accords reveals their important role as "instruments of foreign policy" ([24], p. 94), and of how the US in these agreements is "blatantly protective of US carriers" ([7], p. 57). European attempts aimed at encouraging the US to change its ownership and control restrictions have met with little more than assurances that the issue will be considered in future [15].

Sentiments surrounding the national interest motives of the US also emerged during the final stage interviews. For instance, Interviewee 6 maintained that the US likes to "push free markets, but really they emphasise self-interest". Interviewee 13, who labelled himself "a free market economist" agreed, observing that the US has encouraged liberalization since the mid-1940s, but always "as and when it suits and benefits the US carriers". Given the bilateral system in global aviation is in many ways predicated on national interests $[15,20]$, it is little wonder that wider multilateral liberalization was seen by many experts in this study as likely to be patchy and uneven in future. Europe is evidently pushing against a powerful and entrenched bilateral system globally that is strengthened by geography and a long history of countries defending and protecting their airlines and air markets. As Interviewee 5 argued: "The reality is that the bilateral system exists for a reason" and it will not be replaced any time soon. He went on to highlight its economic benefits which he contended should not simply be "traded away".

\section{Conclusion}

Significant and widespread air market multilateralism outside of Europe does not appear set for uninterrupted advancement in global aviation in the foreseeable future. The trajectory of international multilateral liberalisation will likely be patchy and uneven at best. Clearly Europe's multilateral internal common aviation area makes the trading bloc a significant and powerful actor in global aviation today; however, Europe's global industry power and influence is constrained by the ongoing relevance and scope of the external bilateral system. Big aeropowers such as China and Russia are not enthusiastic supporters of multilateralism in air transport, while major competitors in the Gulf support multilateralism to expand their global reach, yet at the same time are considerable beneficiaries of the bilateral system which has facilitated their growth as a result of their advantageous geographical locations. This context effectively delivers a win-win situation to them, while European airlines are presently sheltered from the full effects of Gulf based competition by this same external bilateral system.

The internal and external air market realities that Europe faces have seen it support multilateralism and free markets internally, but less so externally. In this sense, air market liberalisation remains a multifaceted issue that retains clear internal and external considerations which rarely align. The geopolitics of global aviation also means that different industry stakeholders, such as aircraft manufacturers, airports and airlines each support or reject arguments for increased competition based on the perceived costs and benefits to their competitive position in the aviation value chain and wider economy [13, 34]. The competitive realities that form the basis of the internal European regional single air market, and those that influence and shape its external air market policies and practices, are distinctly different. Nevertheless, Europe still remains a major player in global aviation, and an influential example of how regional multilateral liberalisation can work well. In this sense alone, Europe's internal regional single air market retains the very real potential of shaping the broader global aviation industry well into the future. 


\section{Appendix}

Table 1 Main survey 1: multiple choice questions (MCQs). $(\%=$ expert responses)

\section{Where is the global airline industry headed?}

MCQ5 What will likely be the big news stories for the global airline industry over the coming decade and beyond?

1st Environmental concerns/issues $68 \%$

2nd Airport congestion (including slot allocation) $58 \%$

3rd The continued rise of the major Gulf carriers

4th Infrastructure constraints

5th The rise of the Chinese airline industry $41 \%$ Oil price

MCQ6 Are national flag carriers increasingly becoming a part of history, or are they here to stay?

a. They are definitely disappearing from the global $11 \%$ industry

b. Most of them are here to stay

c. Some of them will survive, but most will likely disappear in the next 10 years or so

d. Other

MCQ7 Which of the following political/economic positions best captures your overall view of the global airline industry and its IDEAL regulatory future?

a. $\quad$ Significant regulation is required because most governments need to closely regulate the airline industry as it is crucial to national economic development and growth

b. Some regulation of air markets will always be needed, however, this reality can (and should) coexist with varying levels of liberalisation heading forward

c. The industry is imperfect and always will be. It is how it is. Likewise, change will almost always be slow and incremental, with significant international liberalisation only occurring on a limited basis (with the exception of the $E U$ )

d. The free market should be the basis for most (if not 21\% all) air markets around the world, with little to no national interference

MCQ8 Globally, at what rate is international air market liberalisation currently progressing at?
a. Too slow
b. About right
c. Too fast
d. No opinion

$39 \%$

$46 \%$

$9 \%$

$6 \%$

MCQ9 Will national sovereignty have less impact on the development of the global airline industry in the foreseeable future?

a. Unlikely, as the nationality-based bilateral system of 19\% air service agreements (ASAs), along with national restrictions on ownership and control, will continue to remain strong

b. Likely, as multilateral ASAs and open skies agreements are progressively taking hold around much of the world
Table 1 Main survey 1: multiple choice questions (MCQs). ( $\%=$ expert responses) (Continued)

c. Its impact will vary and developments will be mixed $42 \%$

MCQ10 Is the European Union (EU) single air market a prime example of the international liberalisation that will happen elsewhere around the world in the foreseeable future?

a. Definitely an example of what is coming for the $3 \%$ global airline industry

b. A prime example, but with slow, patchy and $\quad 59 \%$ uneven progress around the world

c. The EU has followed a mostly unique path to liberalisation, and is unlikely to provide meaningful insights into the future of the industry elsewhere

d. The EU single air market is now actually more a reflection of the US domestic market, than a prime example applicable for other countries and/or regions

MCQ11 Which of the following international regions do you think is most likely to form a regional air bloc (single air market) with full cabotage rights, and no internal restrictions on ownership and control, within the next 10 years or so?

1st EU with surrounding countries $\quad 46 \%$

2nd Australia/New Zealand with surrounding countries $\quad 44 \%$

3rd ASEAN countries

$40 \%$

4th North Atlantic (US \& EU)

The big three global airline alliances - Star, SkyTeam \& oneworld

MCQ12 Are the big three global airline alliances - Star, SkyTeam \& oneworld - a permanent feature of the industry? How would you characterise their future prospects?

a. They will be around for a long time to come $\quad 43 \%$

b. They are facing the real prospect of extinction $\quad 9 \%$

c. Not all three will survive, but two might 25\%

d. Four or more big global alliances are likely to exist $\quad 20 \%$ in the foreseeable future

e. Other

MCQ13 How would you best describe the main rationale for the global airline alliances?

a. Substitutes for full mergers (given regulatory $\quad 14 \%$ barriers)

b. A cost effective way to achieve global geographic $40 \%$ reach and coverage

c. A cheaper option to merging that also achieves economies of scale, scope and density benefits

d. An effective mechanism for turning competitors into $18 \%$ partners

MCQ14 Are bilateral alliances, including agreements between competing alliance members, weakening the major global alliances?

a. Yes, they are weakening the very rationale for the global alliances

b. No, they are just a reflection of the pragmatic $\quad 36 \%$ nature of the industry

c. Somewhat, depending on the exact bilateral $41 \%$ alliance being considered

The North Atlantic and Asian regions 
Table 1 Main survey 1: multiple choice questions (MCQs). (\% = expert responses) (Continued)

MCQ15 How likely do you think it is that the US and EU will create a single North Atlantic air market in the foreseeable future?
a. Zero chance
$6 \%$
b. Unlikely
$44 \%$
c. $\quad 50 / 50$
$34 \%$
d. Likely
$13 \%$
e. Almost certain
$3 \%$

MCQ16 What would be the most significant consequences of such a single North Atlantic marketplace?
a. $\quad$ Flag carriers would soon disappear
$9 \%$
b. Major US carriers would merge with major EU flag $26 \%$ carriers
c. US airlines would develop a significant presence within the EU
d. EU airlines would operate a substantial number of $24 \%$ services within the US
e. Single North Atlantic airline brands would replace $\quad 12 \%$ national brands
f. Other

MCQ17 What role do you think the Asian region will play in shaping the global airline industry over the next decade and beyond?
a. The twenty-first century will be the Asian century and the airline industry will be a big part of this
$39 \%$
b. Asia is losing ground to the Middle East and a resurgent Europe and US
c. Asia will follow the lead from elsewhere, rather than $23 \%$ drive or greatly influence developments throughout the global industry
d. The real story for the global industry in the region is 25\% China, elsewhere developments will be mixed

MCQ18 Will open skies agreements and increasing liberalisation take hold in the Asian region in the foreseeable future?
a. No, the Asian region is too politically fragmented
$30 \%$
b. Yes, it is only a matter of time
$31 \%$
c. Smaller intra-regional single air markets within Asia are more likely

MCQ19 The rise of China is a much discussed and debated contemporary issue. What impact will a bigger and stronger China have on the global airline industry?
a. Massive and far-reaching
$17 \%$
b. The growth story will be significant, but profits will be as elusive as ever
c. Moderate, but mostly a domestic story with less international impacts being felt
d. Limited, as China is likely to play catch-up to other major global regions and industry players for some time to come

\section{Emerging Markets}

MCQ20 What role and impact do you think that India will have on the global airline industry over the next decade or so?

a. Very little; India faces too many challenges that need addressing
Table 1 Main survey 1: multiple choice questions (MCQs). (\% = expert responses) (Continued)

b. A major role and impact is likely in the foreseeable $11 \%$ future as the country continues to grow economically

c. The impact will be significant, but not as significant $33 \%$ as China

MCQ21 How significant do you think the three major Gulf carriers (Emirates, Etihad \& Qatar) are to the global airline industry?

a. The most significant players in the global airline $29 \%$ industry today, and growing more so

b. Significant, but just one of a number of key industry $61 \%$ stories now and into the foreseeable future

c. Not as significant as they would have the industry $\quad 10 \%$ believe

MCQ22 As you scan the world and the global airline industry, what countries and/or regions do you think will rise to feature more prominently throughout the industry in the coming decade and beyond?

$\begin{array}{ll}\text { 1st China } & 80 \% \\ \text { 2nd Asia } & 50 \% \\ \text { 3rd India } & 34 \% \\ 4 \text { th Brazil } & 29 \% \\ 5 \text { th Indonesia } & 26 \% \\ 6 \text { th Africa } & 17 \% \\ 7 \text { th North Atlantic } & 13 \% \\ \text { Iran was the only country or region added to 'other' here. } & 1.4 \%\end{array}$

Note: Percentage totals exceeding $100 \%$ for a MCQ are multiple response questions whereby participants could select more than one option if they wished 
Table 2 Main survey 2: 27 forecasts

\begin{tabular}{|c|c|c|c|c|c|c|}
\hline \multicolumn{2}{|c|}{ Forecast } & \multirow{2}{*}{$\begin{array}{l}\text { Disagree } \\
9 \%\end{array}$} & \multirow{2}{*}{$\frac{\text { Neutral }}{18 \%}$} & \multirow{2}{*}{ Agree } & \multirow[t]{2}{*}{ Consensus $^{1}$} & \multirow{2}{*}{$\frac{\text { Mean }^{2}}{3.85}$} \\
\hline $\mathrm{F} 1$ & $\begin{array}{l}\text { It is vitally important that the global airline industry develop a comprehensive } \\
\text { response to climate change in the foreseeable future. }\end{array}$ & & & & & \\
\hline F2 & $\begin{array}{l}\text { The global airline industry will develop a comprehensive response to climate } \\
\text { change and as a result substantially reduce its carbon emissions within the next } 10 \\
\text { years or so. }\end{array}$ & $29 \%$ & $18 \%$ & $53 \%$ & & 3.32 \\
\hline F3 & $\begin{array}{l}\text { Recent attempts by the EU to include aviation in its emissions trading scheme (ETS), } \\
\text { although unpopular with many airlines, is a likely future model of how to effectively } \\
\text { deal with global airline industry emissions. }\end{array}$ & $26.5 \%$ & $23.5 \%$ & $49 \%$ & & 3.29 \\
\hline F4 & $\begin{array}{l}\text { Even if liberalisation increases around the world over the next decade, indirect } \\
\text { regulations like airport congestion and other infrastructure constraints will moderate } \\
\text { or limit any potential benefits. }\end{array}$ & $12 \%$ & $12 \%$ & $76 \%$ & $76 \%$ & 3.74 \\
\hline F5 & $\begin{array}{l}\text { Re-regulation is likely to slow efforts towards greater liberalisation for much of the } \\
\text { global airline industry over the next decade or so. }\end{array}$ & $47 \%$ & $26 \%$ & $27 \%$ & & 2.82 \\
\hline F6 & $\begin{array}{l}\text { Most international airlines have not responded effectively to historically and } \\
\text { persistently high oil prices, and are unlikely to do so in the foreseeable future. }\end{array}$ & $38 \%$ & $27 \%$ & $35 \%$ & & 2.97 \\
\hline F7 & $\begin{array}{l}\text { The global airline industry would have higher levels of overall future profitability if } \\
\text { more consistently underperforming and loss making airlines were allowed to fail } \\
\text { and exit the industry. }\end{array}$ & $15 \%$ & $9 \%$ & $76 \%$ & $76 \%$ & 3.94 \\
\hline F8 & $\begin{array}{l}\text { Profitability will be a key measure of global airline industry progress and } \\
\text { development over the next } 10 \text { years or so. }\end{array}$ & $3 \%$ & $15 \%$ & $82 \%$ & $82 \%$ & 4.03 \\
\hline F9 & $\begin{array}{l}\text { Bilateralism will still be a significant force and influence for the global airline } \\
\text { industry into the foreseeable future. }\end{array}$ & $6 \%$ & $9 \%$ & $85 \%$ & $85 \%$ & 3.88 \\
\hline F10 & $\begin{array}{l}\text { The global airline industry is not well suited to free market principles now, or into } \\
\text { the future. }\end{array}$ & $35 \%$ & $24 \%$ & $41 \%$ & & 3.06 \\
\hline F11 & $\begin{array}{l}\text { In a massive and highly complex system like the global airline industry, the EU can } \\
\text { provide interesting insights into its likely future, but beyond that, its power and } \\
\text { influence to shape the industry's future development is limited. }\end{array}$ & $3 \%$ & $17 \%$ & $74 \%$ & & 3.74 \\
\hline F12 & $\begin{array}{l}\text { Regional air blocs (single air markets) similar to that currently represented by the } \\
\text { EU, will become the dominant market structure for the global airline industry in the } \\
\text { next } 10 \text { years or so. }\end{array}$ & $23 \%$ & $15 \%$ & $62 \%$ & & 3.44 \\
\hline F13 & $\begin{array}{l}\text { Full (or close to it) international air market liberalisation is inevitable; the only area } \\
\text { of real debate concerns how long it will take to achieve. }\end{array}$ & $41 \%$ & $12 \%$ & $47 \%$ & & 3.06 \\
\hline F14 & $\begin{array}{l}\text { Greater or limited future international liberalisation will not substantially impact the } \\
\text { future development of the major global alliances. }\end{array}$ & $35 \%$ & $18 \%$ & $47 \%$ & & 3.12 \\
\hline F15 & $\begin{array}{l}\text { Buying substantial equity stakes ( } 10 \% \text { or higher) in other airlines is becoming a } \\
\text { more effective way for individual airlines to build strong and lasting partnerships } \\
\text { than simply codesharing, global alliance membership or strategic agreements. }\end{array}$ & $17 \%$ & $15 \%$ & $68 \%$ & & 3.5 \\
\hline F16 & Strategic partnering outside global alliance structures will become a significant & $3 \%$ & $12 \%$ & $85 \%$ & $85 \%$ & 4.01 \\
\hline
\end{tabular}
feature of the airline industry over the next 10 years or so.

F17 How would you characterise the likely future strategic position of each of the three big global alliances in 10 years or so from now?

$$
\begin{aligned}
& \text { a Star Alliance } \\
& \text { b SkyTeam } \\
& \text { c oneworld }
\end{aligned}
$$

Forecast

F18 US foreign airline ownership and control restrictions will not be lifted or eased any time soon.

F19 EU flag carriers, particularly Air France, British Airways and Lufthansa, will still be the dominant European airlines for long-haul flights 10 years or so from now.

F20 Asian countries like China, with actual or potential domestic air markets of significant size, are highly unlikely to grant unrestricted (open) market access to foreign airlines into the foreseeable future (and mostly, if not exclusively, on a bilateral basis only).

F21 The big three Chinese carriers will become global airlines on par with major international competitors within the next 10 years or so.

$\begin{array}{lllll}3 \% & 12 \% & 85 \% & \mathbf{8 5} \% & 4.01 \\ \text { Weaker } & \text { Unchanged } & \text { Stronger } & \\ 12 \% & 26 \% & & 62 \% & \\ 30 \% & 35 \% & & 35 \% & \\ 29 \% & 18 \% & & 53 \% & \\ \text { Disagree } & \text { Neutral } & \text { Agree } & \text { Consensus } & \text { Mean } \\ 9 \% & 18 \% & 73 \% & & 3.88 \\ 12 \% & 15 \% & 73 \% & & 3.82 \\ & & & & \\ 6 \% & 6 \% & 88 \% & \mathbf{8 8} \% & 4.12 \\ & & & & \\ & & & & \\ \text { Unlikely } & \text { Neutral } & \text { Likely } & \text { Consensus } & \text { Mean }\end{array}$


Table 2 Main survey 2: 27 forecasts (Continued)

\begin{tabular}{|c|c|c|c|c|c|c|}
\hline \multicolumn{2}{|c|}{ Forecast } & \multirow{2}{*}{$\begin{array}{l}\text { Disagree } \\
15 \%\end{array}$} & \multirow{2}{*}{$\frac{\text { Neutral }}{15 \%}$} & \multirow{2}{*}{$\frac{\text { Agree }}{70 \%}$} & \multirow[t]{2}{*}{ Consensus $^{1}$} & \multirow{2}{*}{$\frac{\text { Mean }^{2}}{3.64}$} \\
\hline & a Air China & & & & & \\
\hline & b China Southern & $12 \%$ & $27 \%$ & $61 \%$ & & 3.64 \\
\hline & c China Eastern & $16 \%$ & $28 \%$ & $56 \%$ & & 3.47 \\
\hline \multicolumn{2}{|c|}{ Forecast } & Disagree & Neutral & Agree & Consensus & Mean \\
\hline$F 22$ & $\begin{array}{l}\text { China's airline industry will rival those of the US and EU within the next } 10 \text { years or } \\
\text { so. }\end{array}$ & $9 \%$ & $20 \%$ & $71 \%$ & & 3.62 \\
\hline$F 23$ & $\begin{array}{l}\text { It is currently not possible to accurately predict the nature and extent of India's } \\
\text { impact on the global airline industry over the next } 10 \text { years or so. }\end{array}$ & $21 \%$ & $6 \%$ & $73 \%$ & & 3.73 \\
\hline$F 24$ & $\begin{array}{l}\text { Within the next } 10 \text { years or so, the strategy of attempting to restrict access to the } \\
\text { major Gulf carriers will have mostly (if not totally) failed. }\end{array}$ & $26 \%$ & $21 \%$ & $53 \%$ & & 3.35 \\
\hline$F 25$ & $\begin{array}{l}\text { The three major Gulf carriers will not be able to fully realise their global ambitions } \\
\text { without significant further international liberalisation. }\end{array}$ & $15 \%$ & $17 \%$ & $68 \%$ & & 3.59 \\
\hline \multirow[t]{4}{*}{ F26 } & $\begin{array}{l}\text { In } 10 \text { years or so, which of the following alliance options is most likely to be the } \\
\text { case for each of the major Gulf carriers? }\end{array}$ & Star & SkyTeam & oneworld & Unaligned & New alliance \\
\hline & a Emirates Airline & $20 \%$ & $3 \%$ & $23 \%$ & $47 \%$ & $7 \%$ \\
\hline & b Etihad Airways & $24 \%$ & $17 \%$ & $10 \%$ & $35 \%$ & $14 \%$ \\
\hline & c Qatar Airways & $10 \%$ & $16 \%$ & $58 \%$ & $13 \%$ & $3 \%$ \\
\hline \multicolumn{2}{|c|}{ Forecast } & Disagree & Neutral & Agree & Consensus & Mean \\
\hline$F 27$ & $\begin{array}{l}\text { The global airline industry has a lot more 'global' yet to come in terms of more } \\
\text { regions and countries being drawn into its architecture. }\end{array}$ & $3 \%$ & $20 \%$ & $77 \%$ & $77 \%$ & 3.82 \\
\hline
\end{tabular}

Notes

${ }^{1}$ Consensus being set at $75 \%$ or higher was used as a tool to deepen insights and not as a prescriptive one dimensional metric

${ }^{2}$ The agreement mean was calculated by assigning 1 to strongly disagree through to 5 for strongly agree. In this context, disagree and agree values in the above table include strongly for each, with the mean indicting the strength of that disagreement/agreement out of 5

Table 3 Regions of best industry knowledge (experts)

\begin{tabular}{llll}
\hline Region & Main survey 1 & Main survey 2 & Interviews \\
\hline Europe & $23 \%$ & $23 \%$ & $14 \%$ \\
Asia & $22 \%$ & $26 \%$ & $31 \%$ \\
Oceania & $19 \%$ & $20 \%$ & $31 \%$ \\
North America & $17 \%$ & $15 \%$ & $10 \%$ \\
Middle East & $10 \%$ & $9 \%$ & $7 \%$ \\
India & $4 \%$ & $3 \%$ & $3.5 \%$ \\
Latin America & $2 \%$ & $4 \%$ & $3.5 \%$ \\
Africa & $>1 \%$ & $0 \%$ & $0 \%$
\end{tabular}

The researcher's location in Australia at the time of the study likely explains the distribution here to some extent, especially for the interviews. Linz [22] demonstrated this point while based in Germany; his study's expertise profile was: "Europe (49\%) and North America (25\%), Asia (9\%), South-America (7\%), Africa (5\%), and Oceania (5\%)" (p. 30). It should also be noted that aviation expertise is logically concentrated in the major world air markets of North America, Europe and Asia in any case [22] 


\section{Acknowledgements}

Thank you to two anonymous reviewers for their valuable and constructive feedback.

\section{Author's contributions}

Sole author. The author(s) read and approved the final manuscript.

\section{Funding}

The author/s disclosed receipt of the following support for the research, authorship, and/or publication of this article: The research was supported by an Australian Postgraduate Award (APA) doctoral scholarship awarded by the Australian Government.

\section{Availability of data and materials}

$\mathrm{PhD}$ thesis and underpinning data available at: https://hdl.handle.net/195 $9.11 / 23094$

\section{Competing interests}

The author owns Qantas Airways (QAN) shares.

Received: 15 July 2019 Accepted: 8 March 2020

Published online: 24 March 2020

\section{References}

1. Baur, J. (2010). EU-Russia aviation relations and the issue of Siberian Overflights. Air and Space Law, 35(3), 225-247 Retrieved from https://www. kluwerlawonline.com.

2. Bolger, F., \& Wright, G. (2011). Improving the Delphi process: Lessons from social psychological research. Technological Forecasting and Social Change, 78(9), 1500-1513. https://doi.org/10.1016/j.techfore.2011.07.007.

3. Button, K. (2009). The impact of US-EU "open skies" agreement on airline market structures and airline networks. Journal of Air Transport Management, 15(2), 59-71. https://doi.org/10.1016/j.jairtraman.2008.09.010.

4. Christidis, P. (2016). Four shades of Open Skies: European Union and four main external partners. Journal of Transport Georgraphy, 50, 105-114. https:// doi.org/10.1016/j.jtrangeo.2015.04.005.

5. de Vaus, D. A. (2014). Surveys in social research (6th ed.). London: Routledge.

6. Dobruszkes, F., \& Graham, A. (2016). Air transport liberalisation and airline network dynamics: Investigating the complex relationships. Journal of Transport Geography, 50, 1-3. https://doi.org/10.1016/j.jtrangeo.2015.08.004.

7. Doganis, R. (2010). Flying off course: Airline economics and marketing (4th ed. ). London: Routledge, Taylor \& Francis Group.

8. Dolnicar, S., Grabler, K., Grün, B., \& Kulnig, A. (2011). Key drivers of airline loyalty. Tourism Management, 32(5), 1020-1026. https://doi.org/10.1016/j. tourman.2010.08.014.

9. European Commission (2019). International aviation: ECAA. European Commission. Retrieved from https://ec.europa.eu/transport/modes/air/ international aviation/country index/ecaa en

10. Forsyth, P. (2012). The economics of 7th freedom. In J. F. O'Connell \& G. Williams (Eds.), Air transport in the 21st century: key strategic developments (pp. 211-233). Farnham: Ashgate Publishing Limited.

11. Fox, S. J. (2014). The evolution of aviation in times of war and peace: Blood, tears, and salvation. International Journal on World Peace, 31(4), 49-79. https://doi.org/10.1504/IJPL.2015.066719.

12. Gaspari, F. (2011). Recent developments in EU air transport liberalization and re-regulation policies and the new legal order of international air transport. Issues in Aviation Law and Policy, 11, 415 Retrieved from http://heinonline.org.

13. Hanlon, P. (2008). Global airlines: competition in a transnational industry (3rd ed.). Oxford: Butterworth-Heinemann.

14. Havel, B. F., \& Sanchez, G. S. (2011). Do we need a new Chicago convention? Issues in Aviation Law and Policy, 11(1), 7-22 Retrieved from https://papers.ssrn.com.

15. Havel, B. F., \& Sanchez, G. S. (2014). The principles and practice of international aviation law. New York: Cambridge University Press.

16. Hussler, C., Muller, P., \& Rondé, P. (2011). Is diversity in Delphi panelist groups useful? Evidence from a French forecasting exercise on the future of nuclear energy. Technological Forecasting and Social Change, 78(9), 16421653. https://doi.org/10.1016/j.techfore.2011.07.008.

17. IATA. (2018). Annual review 2018. Montreal, Canada: International Air Transport Association Retrieved from: https://www.iata.org/publications/ Documents/iata-annual-review-2018.pdf.
18. Knibb, D. (2015a). Analysis: Why and how badly is liberalisation stalled? Airline Business. Retrieved from http://www.flightglobal.com/news/articles/ analysis-why-and-how-badly-is-liberalisation-stalled-408503/?cmpid= NLC|FGFG|FGABN-2015-0227-GLOB|news\&sfid=70120000000taAf [Paywall].

19. Knibb, D. (2015b). Long road to open skies. Airl Bus, 31(10), 40-42.

20. Lawton, T. C. (1999). Governing the skies: Conditions for the Europeanisation of airline policy. Journal of Public Policy, 19(01), 91-112 Retrieved from https://www-cambridge-org.

21. Lentz, C. A. (2009). The modified ask-the-experts Delphi method: the conundrum of human resource experts on managament participation the refractive thinker: research methodology (Vol. II, pp. 51-81). Las Vegas: The Refractive Thinker Press.

22. Linz, M. (2012). Scenarios for the aviation industry: a Delphi-based analysis for 2025. Journal of Air Transport Management, 22, 28-35. https://doi.org/10. 1016/j.jairtraman.2012.01.006.

23. Lohmann, G., \& Vianna, C. (2016). Air route suspension: The role of stakeholder engagement and aviation and non-aviation factors. Journal of Air Transport Management, 53, 199-210. https://doi.org/10.1016/j.jairtraman. 2016.03.007.

24. Lykotrafiti, A. (2015). Liberalisation of international civil aviation - Charting the legal flightpath. Transport Policy, 43, 85-95. https://doi.org/10.1016/j. tranpol.2015.05.008

25. Mason, K. J., \& Alamdari, F. (2007). EU network carriers, low cost carriers and consumer behaviour: a Delphi study of future trends. Journal of Air Transport Management, 13, 299-310. https://doi.org/10.1016/j.jairtraman. 2007.04.011.

26. Manzini, P., \& Masutti, A. (2012). The application of the EU ETS system to the aviation sector: From legal disputes to international retaliations? Air and Space Law, 37(4 \& 4), 307-324 Retrieved from https://www.kluwerlawonline.com.

27. Melander, L. (2018). Scenario development in transport studies: Methodological considerations and reflections on delphi studies. Futures, 96 68-78. https://doi.org/10.1016/j.futures.2017.11.007.

28. Nayar, B. R. (1995). Regimes, power, and international aviation. International Organization, 49(01), 139-170. https://doi.org/10.1017/S0020818300001600.

29. Njoya, E.T. (2016). Africa's single aviation market: the progress so far. Journal of Transport Geography, 50, 4-11. doi: https://doi.org/10.1016/j.jtrangeo. 2015.05.009

30. Nowack, M., Endrikat, J., \& Guenther, E. (2011). Review of Delphi-based scenario studies: Quality and design considerations. Technological Forecasting and Social Change, 78(9), 1603-1615. https://doi.org/10.1016/j. techfore.2011.03.006

31. Parente, R., \& Anderson-Parente, J. (2011). A case study of long-term Delphi accuracy. Technological Forecasting and Social Change, 78(9), 1705-1711. https://doi.org/10.1016/j.techfore.2011.07.005.

32. Pitfield, D. E. (2009). The assessment of the EU-US open skies agreement: The counterfactual and other difficulties. Journal of Air Transport Management, 15(6), 308-314. https://doi.org/10.1016/j.jairtraman.2009.04.002.

33. Reuters (2019). China and European Union sign landmark aviation deals. Reuters. Retrieved from https://uk.reuters.com/article/us-china-eu-aviation/ china-and-european-union-sign-landmark-aviation-deals-idUKKCN1SQ1GL

34. Rhoades, D. L. (2016). Evolution of international aviation: Phoenix rising (3rd ed.). London: Routledge - Taylor \& Francis Group.

35. Sjögren, S., \& Söderberg, M. (2011). Productivity of airline carriers and its relation to deregulation, privatisation and membership in strategic alliances. Transportation Research Part E: Logistics and Transportation Review, 47(2), 228-237. https://doi.org/10.1016/j.tre.2010.09.001.

36. Surowiecki, J. (2013). The wisdom of crowds: Why the many are smarter than the few. London: Abacus.

37. Tan, A. K.-J. (2014). The future of multilateral liberalisation of air transport in Asia. In D. Duval (Ed.), Air transport in the Asia Pacific (pp. 259-275). Farnham: Ashgate Publishing Limited.

38. Vasigh, B., Fleming, K., \& Tacker, T. (2013). Introduction to transport economics: From theory to applications (2nd ed.). Farnham: Ashgate Publishing Limited.

39. Wang, J. J., \& Heinonen, T. H. (2015). Aeropolitics in East Asia: An institutional approach to air transport liberalisation. Journal of Air Transport Management, 42, 176-183. https://doi.org/10.1016/j.jairtraman.2014.10.002.

\section{Publisher's Note}

Springer Nature remains neutral with regard to jurisdictional claims in published maps and institutional affiliations. 